\title{
SDGS, SMART URBANISATION AND POLITICS: STAKEHOLDER PARTNERSHIPS AND ENVIRONMENTAL CASES IN MALAYSIA
}

\author{
SENG BOON LIM*1, JALALUDDIN ABDUL MALEK ${ }^{1}$, MOHD YUSOF HUSSAIN ${ }^{1}$, ZURINAH \\ TAHIR $^{1}$ AND NOR HISHAM MD SAMAN ${ }^{2}$
}

${ }^{1}$ Center for Research in Development, Social and Environment, Faculty of Social Science and Humanities, Universiti Kebangsaan Malaysia. ${ }^{2}$ Department of Town \& Regional Planning, Faculty of Architecture, Planning \& Surveying, Universiti Teknologi Mara (Perak Branch).

*Corresponding author:lims@ukm.edu.my

Submitted final draft: 22 July 2020

Accepted: 27 August 2020

http://doi.org/10.46754/jssm.2021.06.016

\begin{abstract}
Consequent to the declaration of achieving the sustainable development goals (SDGs) by United Nations in 2016, most of the countries with capitalist politics have chosen to adopt "smart urbanisation" as a tool to help them gear up for national development. However, research shows that most countries, including Malaysia, are not on the right track. Thus, this research paper aims to examine the alternative political policies besides that of a capitalist/liberal democracy, such as ecological democracy, that the Malaysian smart urbanisation movement should follow to achieve the SDGs. This study applied the method of case study analysis in examining empirical examples related to stakeholder partnerships and environmental cases in smart urbanisation in Malaysia. This paper argues that achieving the SDGs with the current capitalist hegemony poses a significant challenge to countries. However, with environmental ethics in mind, it is possible to achieve the SDGs with the trust granted by the government in the form of participatory politics. The SDGs also need to be overhauled and rewritten under the realm of ecological democracy. The implications of the findings include creating a call for support for an emerging ecological democracy that is particularly compatible with the SDGs as well as embedded in the natural environment, social and economic developments.
\end{abstract}

Keywords: Capitalism, ecological democracy, participatory politics, smart city, sustainability.

\section{Introduction}

The Sustainable Development Goals (SDGs) were proposed by the United Nations General Assembly and came into force in January 2016 as a result of a consensus among leaders of developed and developing countries in their effort to achieve two major anthropocentric visions, i.e., fostering human prosperity and rights; and one supplementary vision of protecting the planet (United Nations [UN], n.d.-b).

As shown in Table 1 , about $76 \%$ of the 17 SDGs are focused on humankind rather than the environment and its non-human content. Only $24 \%$ of the goals are of a supplementary biocentric focus. Hence, it is evident that the priority is for human gains, inevitably causing detrimental effect to the environment and its non-human inhabitants (Keitsch, 2018).
Today, with a short timeframe of less than 15 years to achieve the 2030 Agenda for Sustainable Development, the fate of the SDGs is predominantly in the hands of country leaders and their political ideology. This is especially about the legal adoption of the SDGs, such as the setting up of a national framework for sustainable development policies. Until today, the "saving the planet" task has never gained ownership of the larger realm of regional, sub-national, or global level organisations as they only play the monitoring role such as conducting reviews and follow-ups (UN, 2018). For instance, the role of the United Nations Development Programme (UNDP) is to help implement the SDGs through their work in some 170 countries and territories.

Currently, half of the world's population has chosen to live densely packed urban areas, and this trend is projected to increase to twothirds of the world's population in the year 2050 
Table 1: The focus of SDGs and its assumed roles

\begin{tabular}{|c|c|c|c|}
\hline Focus & Type of Goals & $\begin{array}{c}\text { No. of Goals } \\
\text { (total } 17 \\
\text { SDGs) } \\
\end{array}$ & Assumed Roles \\
\hline \multirow{2}{*}{$\begin{array}{l}\text { Anthropocentric focus } \\
\text { on humankind, rather } \\
\text { than environment and } \\
\text { its non-human contents } \\
\qquad(76 \%)\end{array}$} & $\begin{array}{l}\text { 1) Profit/Human Prosperity } \\
\text { (basic and economic needs) }\end{array}$ & $8(47 \%)$ & Mover, the priority \\
\hline & $\begin{array}{l}\text { 2) People's Social needs (and } \\
\text { rights) }\end{array}$ & $5(29 \%)$ & $\begin{array}{l}\text { Mediator, foster } \\
\text { partnerships }\end{array}$ \\
\hline $\begin{array}{l}\text { Supplementary- } \\
\text { biocentric }\end{array}$ & $\begin{array}{l}\text { 3) Planet protection (on } \\
\text { animals, plants, land, air, sea } \\
\text { and climate change) }\end{array}$ & $4(24 \%)$ & $\begin{array}{l}\text { Human "resources" to } \\
\text { sacrifice in exchange } \\
\text { for growth }\end{array}$ \\
\hline
\end{tabular}

Source: The researchers' compilation from the UN (n.d.-a, 2018)

(UN, 2014). As a result, smart urbanisation has been used as one of the tools by world leaders in achieving their political and administrative motives, "hiding" behind the ambiguous vision of quality living for their constituents in the pre-defined boundary of the geography of the nation. In this research paper, smart urbanisation refers to Information and Communications Technology (ICT) solutions, which are a type of urban development movement (Hollands, 2016). This seems to be the right time for leaders to embark on smart urbanisation, such as the "intelligent island" vision that has been turned into the "smart nation" vision by the Singaporean government, "100 smart cities vision" by the Indian government, and the formulation of the national smart city framework by the Malaysian government (Lim et al., 2020). These trends are due to the smart urbanisation concept that promises huge market values (Hollands, 2015), albeit still in the nascent stages of development (Luque-Ayala \& Marvin, 2015) and yet is believed to be suitable in achieving the SDGs. In the rollout of both smart urbanisation and SDGs, most leaders have chosen to adopt the capitalism/liberal ideology based on the consensus (Cardullo \& Kitchin, 2018) that prosperity (market, profit, and choice) comes first and then followed by government, civil society, and nature.

Under the hegemonic capitalist ideology, it seems that leaders have achieved confidence in promoting both the SDGs and smart urbanisation. However, evidence from the 2018 SDG Index and Dashboards Report shows that none of the developed and developing nations in the world is on track towards achieving all the goals by 2030 and the slowest progress is being made on some of the environmental goals (Abdul Hamid, 2018). Malaysia is on a downward trend, as the country is moving in the wrong direction in climate action (SDG 13) and charting a stagnant trend in building sustainable cities and communities (SDG 11) (Sachs et al., 2018, pp. 288-289).

Thus, this paper aims to examine other alternative politics, besides capitalist/liberal democracy, such as ecological democracy that the Malaysian smart urbanisation movement should follow in order to achieve the SDGs. This study applied the method of case study analysis in examining empirical examples concerning stakeholder partnerships and environmental cases in Malaysia. In the following section, topics on political ecology, the SDGs and the types of goals, comparison of the characteristics of capitalism and ecological democracy and smart urbanisation and politics in Malaysia are reviewed. Then, the researchers explain the research method of case analysis and findings on empirical cases in Malaysia. Finally, suggestions, contributions and the conclusion of the study are discussed. 


\section{Literature Review}

This section is divided into four subsections that provide an analytical framework as the foundation for this paper. To begin with, subsection a) discusses sustainable development, community involvement and smart urbanisation by framing the discourse via the political ecology lens. This subsection is pivotal as it lays down the compass for this paper's empirical navigation. Subsequently, subsection b) outlines the relationship between smart urbanisation, SDGs goals and the sustainable development agenda in a general sense. Consequently, to unveil the paradox and rhetoric of the political ideologies in dealing with smart urbanisation and its relationship with sustainable development, subsection c) compares capitalism with ecological democracy. Finally, subsection d) provides a discussion on the role of politics in shaping smart urbanisation and sustainable development discourse in Malaysia.

\section{Sustainable Development, Community Involvement and Smart Urbanisation}

This paper employs political ecology in its approach and views environmental change, ecological conditions and instability as products of the political process and neo-liberal agenda. The approach pays special attention to social justice and environmental disputes (Bryant, 2015; McCarthy \& Prudham, 2004; Perreault, Bridge, \& McCarthy, 2015; Walker, 2005). The main narrative of political ecology is that environmental science and its main concepts rationality, scientific and positivism approach in addressing man-made products - do not happen in a void. Instead, environmental decision-making and smart urbanisation for that matter are subjected to political bargaining and competing interests amongst the actors involved in the environment - state, corporations, local people and media, among others. In this sense, the political ecologist investigates the products beyond the numerical, index and environmental rhetoric. It places special attention on the role of actors in shaping policy outcomes or, in this paper's case, smart urbanisation.
This paper posits that it would be naïve yet incomplete if a smart city - the product of society and the man-made environment ignores the role of politics as a dominant force in shaping the discourse in Malaysia. The belief stems from two fundamental reasons that force the emergence of political ecology. First, environmental science is affected by social and political factors. Ergo, to understand the fundamental biophysical causes of perceived environmental problems requires understanding both forces.

Second, policies based on unreconstructed science produce environmental policies that penalize and increase environmental degradation and poverty by threatening the livelihood of land users (Forsyth, 2003).

Clearly, the sources of successful, efficient and meaningful smart urbanisation partnerships are varied. However, zooming into the aspect of distributional power in managing, i.e., the decision-making of the smart urbanisation discourse, it is evident that political will ability to fulfill the desired outcomes of earlier commitments - is the main criterion in assessing stakeholder partnerships. In addition, it has been observed that the political culture in developing countries demonstrates a weaker democracy and fewer check and balance elements as compared to in developed countries. These inadequacies have caused natural resources and development projects to become sources of rent-seeking - an economic concept that occurs when an entity seeks to gain added wealth without any reciprocal contribution of productivity (Dryzek, 2005; Jomo \& Wee, 2002; Sawyer \& Gomez, 2012; Sloane-White \& Beaulieu, 2010). Above all, the priority and concern of politicians in developing countries, including Malaysia, is on economic growth as a prime indicator of the leadership's capability. In this sense, economic performance supersedes environmental concerns. Such an approach is a clear trait of the developmental state, which according to Kurer (1996, p. 647) is "a commitment to economic development by the political and bureaucratic elite, a high degree of state autonomy and thus 
a weak and subordinated civil society and a powerful, competent and insulated economic bureaucracy."

Subscribing political ecology as a lens for understanding the smart urbanisation discourse requires the researchers to be aware on the technocratic way and participatory approach in handling the decision-making and partnership process - as this action demonstrates the role of actors in shaping policy implementation, including the smart urbanisation discourse (Bryant, 2015; Dente, 2014; Thomas, 2013). Technocratic and participatory approaches are two general development orientations that revolve around the top-down and bottom-up approaches, respectively.

Public participation in the participatory approach is a political tool in distributing the power of decision-making, which tends to neglect social study or public involvement in the decision-making process (Barrow, 2010; Kakonen \& Hirsh, 2009; Lockie, 2001). Meanwhile, technocratic is an approach that has been subjugated by elites and heavily relies on the rational concept (Gururani \& Vandergeest, 2014; McDonald-Wilmsen \& Webber, 2010).

Even though the stakeholder partnership process has been institutionalised in Malaysia's land use and environmental management mechanism, in reality, the process receives little attention if not poor treatment from the state, private sector and corporations (NorHisham \& Ho, 2015, 2016). Efforts to empower smart urbanisation beyond information and communications technology, software and hardware are a daunting task. It is against this background that environmental science and its main concepts - rationality, scientific, objective and technical - become myths and the participatory process serves merely as a symbol of law, decoupling, formality, facadism, window dressing and lip service (Nor-Hisham \& Ho, 2016).

\section{ICT-driven Smart Urbanisation, SDGs and the Types of Goals}

ICT solution/technology-enabled smart urbanisation is dominating the global north and global south. The common practices of technology-led implementation strategies include top-down governance where citizens are mostly recommended to follow the social algorithm order, double-helix model (government and private sectors) to promote the privatisation of smart city projects with an emphasis on capital gains activities and placated by the sustainable growth model (Lim et al., 2020). These technological characteristics are easily accepted by the public due to the compatibility with the current neoliberal logic (Cardullo \& Kitchin, 2018) and all major actors seem to be in win-win-win situations.

For instance, citizens are beneficiaries of technological advances, governments are assisted by the private technology sector in solving urban problems and providing better services to citizens and the private sector gains repeated profits in these ICT-led technoconsumption cycles.

Furthermore, this ICT-enabled corporate smart urbanisation contributes to an expansion of social and political responsibilities, leading to the possible alternative development of commons-oriented smart urbanisation (Niaros, 2016). Commons carries the meaning of peer production or a shared-resource system, where public values to society are emphasized over private values (Brinkley, 2020).

The concept of commons was said to be referred to Elinor Ostrom and is akin to the intelligence and experience of aborigines which stress on the concept of humans as "part of nature" rather than as "nature owners" that have the right to exploit natural resources to no limits (Lim, 2020). Currently, the internet, computer networks, 3D-printers and computer numerical control (CNC) are examples of the tools of commons that have gained popularity under the trend of smart urbanisation and democratizing the way of production (Kostakis \& Bauwens, 2014). 
Examples of the possible commons-oriented smart practice include the Fab Lab turned into the Fab City project in Barcelona (Fab City, 2018), Medialab Prado in Spain and Metalab Viena in Austria (Niaros, 2016). Due to the rapid growth in ICT development, these examples have the characteristics of a common pool of resource practices that are aimed at being scaled globally. However, this commons-oriented smart practice is still at the infancy stage. It needs to be continuously nurtured with emphasis on global public values, broader citizen participation, continuous circulation of commons and building the collaboration networks.

However, in today's capitalist world, the principles of commons are always being subjugated compared to human prosperity and economic growth issues. As indicated in Table 2, out of the 17 SDGs, the majority or eight goals are on the vision of achieving human prosperity (basic and economic needs), five goals are for social needs (and rights) while the remaining four goals are for the protection of the planet (on land, air, sea and climate change).

Table 2: SDGs and their visions, needs and actions/issues

\begin{tabular}{|c|c|c|}
\hline SDGs & Action/ Issue & Type of Needs* \\
\hline \multicolumn{3}{|c|}{ Type of Vision: Human Prosperity } \\
\hline G1 No poverty & $\begin{array}{l}\text { Action: Donate what you do not use } \\
\text { Issue: } 836 \text { million people live in extreme poverty }\end{array}$ & $\begin{array}{l}\text { N1 (Basic food/ live/ wear/ } \\
\text { transport survivor needs) }\end{array}$ \\
\hline G2 Zero hunger & $\begin{array}{l}\text { Action: Avoid throwing away food } \\
\text { Issue: Over } 1 / 3 \text { of the world's food is wasted }\end{array}$ & N1 (Basic food need) \\
\hline $\begin{array}{l}\text { G3 Good health and } \\
\text { well-being }\end{array}$ & $\begin{array}{l}\text { Action: Vaccinate your family to protect them and } \\
\text { improve public health }\end{array}$ & $\begin{array}{l}\text { N1 (Basic health need) } \\
\text { N2 (Extended well-being n }\end{array}$ \\
\hline $\begin{array}{l}\text { G7 Affordable and } \\
\text { clean energy }\end{array}$ & $\begin{array}{l}\text { Action: Use only energy-efficient appliances and } \\
\text { light bulbs }\end{array}$ & All types \\
\hline $\begin{array}{l}\text { G8 Decent work and } \\
\text { economic growth }\end{array}$ & $\begin{array}{l}\text { Action: Buy from green companies that are equal } \\
\text { opportunity employers }\end{array}$ & $\begin{array}{l}\text { N1 (Financial stability) } \\
\text { N2 (Gender) }\end{array}$ \\
\hline $\begin{array}{l}\text { G9 Industry, } \\
\text { innovation and } \\
\text { infrastructure }\end{array}$ & $\begin{array}{l}\text { Action: Think of innovative new ways to } \\
\text { repurpose old material }\end{array}$ & $\begin{array}{l}\text { N1 (Financial stability) } \\
\text { N2 (recycling) }\end{array}$ \\
\hline $\begin{array}{l}\text { G11 Sustainable cities } \\
\text { and communities }\end{array}$ & $\begin{array}{l}\text { Action: Bike, walk or use public transportations } \\
\text { to keep our cities' air clean } \\
\text { Issue: There needs to be a future in which cities } \\
\text { provide opportunities for all }\end{array}$ & N1 (Basic clean air and mc \\
\hline $\begin{array}{l}\text { G12 Responsible } \\
\text { production and } \\
\text { consumption }\end{array}$ & Action: Recycle paper, plastic, glass \& aluminium & $\begin{array}{l}\text { N1 (Economic \& productio } \\
\text { N1 (Pollution-plastic) }\end{array}$ \\
\hline \multicolumn{3}{|c|}{ Type of vision: Social/ Rights } \\
\hline G4 Quality education & Action: Help children in your community to read & $\begin{array}{l}\text { N2 (Primary \& secondary } \\
\text { education) } \\
\text { N3 (Tertiary education) }\end{array}$ \\
\hline G5 Gender equality & Action: Call out sexist language and behavior & N2 (Social tolerance) \\
\hline $\begin{array}{l}\text { G10 Reduce } \\
\text { inequalities }\end{array}$ & Action: Raise your voice against discrimination & N3 (Freedom of speech) \\
\hline
\end{tabular}


G16 Peace, justice and strong institutions

G17 Partnerships for the goals
Action: Use your right to elect the leaders in your country and local community

Action: Revitalize the global partnership for sustainable development
N3 (Rights to choose leaders)

N3 (Self-actualization needs)

N1 (Basic water \& sanitation need)

Action: Avoid wasting water Issue: Water scarcity affects more than $40 \%$ of the world's population

G13 Climate action Action: Educate young people on climate change to put them on a sustainable path early on.

N1 (Physiological need)

N2 (Education)

N1 (Ocean \& non-human water life)

N1 (Pollution-plastic)

N1 (Land \& non-human life) N1 (Physiological need)

G15 Life on land

Action: Plant a tree and help protect the environment

3 Desired opportunities

Note: *Types of needs: N1 Basic necessities; N2 Complementary needs; N3 Desired opport
Source: The researchers' compilation (refer to Bakar et al., 2016; Maslow, 1943; UN, 2019)

Among the social goals, the areas of concern include education (Goal 4), gender equality (Goal 5), voicing out against discrimination (Goal 10), the right to elect leaders for peace, justice and strong institutions (Goal 16) and enhancing partnerships (Goal 17).

The last goal of calling for the revitalisation of global partnerships for sustainable development is the most important, as no result can be reaped without solid actions on the ground both in intra- and inter-countries partnerships. These partnerships should be grounded on the quad-helix model where civil society, government, business and academia can come together to create and promote smart cities (Kummitha \& Crutzen, 2017).
Based on the seminal work of Elkington (1997), the triple bottom line for the sustainable development concept is a balanced ratio where there are interactions and "partnerships" between profit (economic growth), people (social inclusion) and planet (environmental protection) (refer Figure 1). However, the current practice of SDGs, as shown in Table 2, reveals a notable disconnection (Hollo, 2018a) and an unbalanced ratio.

It is foreseen that the famous sustainable development definition by the Brundtland Report (WCED, 1987) as "development that meets the needs of the present without compromising the ability of future generations to meet their own needs" will hardly be achieved if countries continue to follow the current path of political development. 


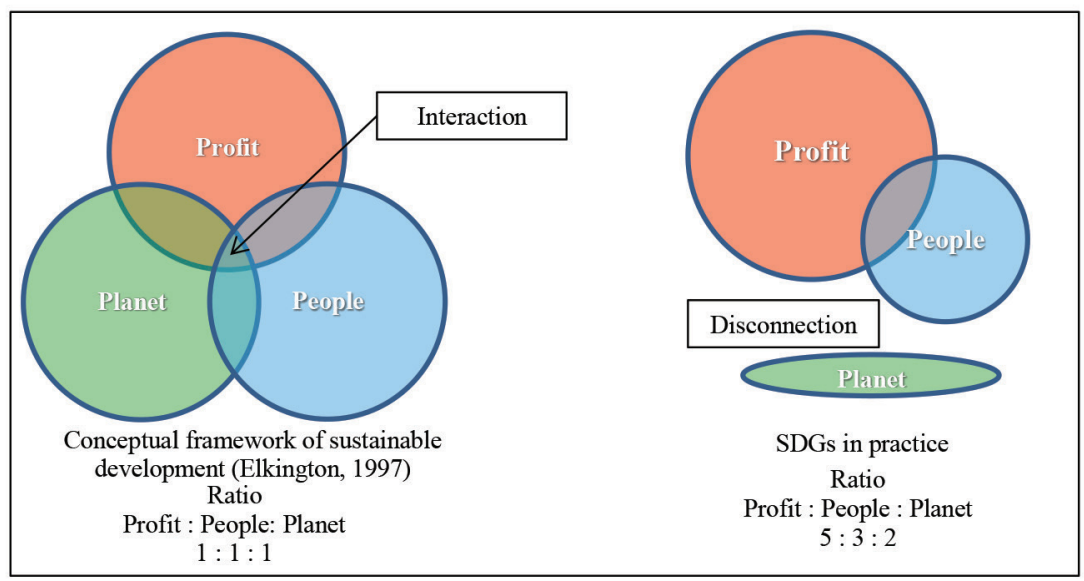

Figure 1: Conceptual framework of sustainable development and the actual practice of SDGs Source: The researchers' compilation from Elkington (1997) and UN (2018)

\section{A Comparison of the Characteristics of Capitalism and Ecological Democracy}

Capitalism is the strongest ideological political force that has ever dominated the world's development. Since the publication of "Wealth of Nations, 1776" by Adam Smith (Preston, 1996) in the eighteenth century until today, the theory of spontaneous order of the marketplace has deeply influenced country leaders in planning the development of their countries and the world. This article discusses the topics of state, market and citizens.

According to Smith's theory, the government (state) should impose minimum interference in the economy and production and consumption markets. Moreover, "citizenship is mostly understood as a set of individual rights and contains only a minimal notion of virtue or mutual responsibilities between members of the polity" (de Waal \& Dignum, 2017). A liberal democracy is another term that is deeply rooted in capitalist ideology. The corporate sector of technology has found a significant gap in the smart city market that has allowed them to penetrate it, persuading country leaders to establish a partnership with them in the name of achieving an urban quality living environment using ICT solutions (Hollands, 2016; Wiig, 2016).
The global internet of things smart city market was estimated to be enormous, achieving US\$1.7 trillion (Poole, 2014) and the whole smart city market could be worth more than US\$32 trillion (NIST, 2014). Meanwhile, political leaders and city administrators/officers prefer to adopt technological reductionism ideas in handling urban issues, e.g., Songdo Smart City, Masdar Smart City and Rio de Janeiro's IBM Command Centre (Kitchin et al., 2017; Komninos \& Mora, 2018; Selinger \& Kim, 2015).

That is the techno-utopian future that was being imagined, is a fairy tale of storytelling and marketing strategy by corporates to gain capital and earn profits (Soderstrom et al., 2014).

Since the vision of SDGs is to gain prosperity for humankind, it is assumed to be compatible to run in parallel with the ICT smart development and that they could be a perfect match for contemporary development strategies. However, if the SDGs' second priority on environmental concerns is examined, the complexity of the problems seems to be ignored because "minimum interference from civic society" and top-down decisions from governments are the ideas expected in a liberal democracy. Although the "choice" and "freedom" of citizens are stressed in a liberal democracy (Muzaffar, 1986; 
Sunstein, 1993), these are all subject to the control of the government and market.

Environmental deterioration issues have continued to take place, e.g., tsunamis, tornados, climate change, rising global temperature and the melting of the glacier. The exploitation of scarce resources for use in smart technology gadgets, such as the illegal mining of coltan in the Democratic Republic of Congo, has created local socio-environmental issues (UN, 2001). Therefore, Kaika (2017) argued that smart cities and ICTs could not be the solution because they are part of the problem. Environmental deterioration continues to happen despite the adoption of the SDGs. Kaika further argued that the effective setting up of smart monitoring technologies in Brussels would probably result in additional socio-environmental destruction in Congo, or that the achievement of the recycling of electronics in London would likely imply that a significant amount of hazardous electronic waste has been dumped to third world countries such as India. The impact of setting up a "smart nation" on the environment has been downplayed by leaders and economists who choose to rationalize it with acceptable sacrifices to show continuous growth in their local human wealth.

Kathleen (2019) unveiled how Singapore's hunger for sand, mining about 70 million tonnes of sand from Cambodia for land-filling to attain its "smart nation vision" (Ho, 2017), is indirectly destroying Cambodia's coastlines and villages. Thus, have the advanced smart cities' dredging technologies seen utilised in sand mining uplifted the planet's protection vision? Meanwhile, Ho (2017) criticized that smart urbanisation has been used as a technological tool or strategy for Singapore to establish its authoritarian power under the notion of neoliberal socio-politic. It is expected that the negative environmental impact of smart urbanisation will prevail in the future on the planet we inhabit and one day the planet could be destroyed by human hands (Yigitcanlar et al., 2019).

According to Yigitcanlar et al. (2019), the current smart city practice could be a zero-sum game for sustainability, where environmental gains are diluted by the dominance of ICTfocused solutions. Most of the solutions are, in fact, meant for human gains and saving the planet is secondary. Therefore, the question is, what does the humankind want? People emphasize on economic prosperity and the quality of life, they can bear environmental deterioration as long as it does not affect them directly and they keep ignoring the situation for as long as they have agreed, feeling guiltless and assured by the circle of capitalist like-minded people. One example reflecting such human wants is the dumping of plastic waste from developed countries to third world countries in the name of "recycling" (Little, 2019).

This argument on what humans actually want goes back to the consideration of the relationship between humans and the environment (Bakar et al., 2016), i.e., whether humans are separated from the environment. Hollo (2018a) argues that one could not work to improve humanity without cherishing and stewarding the natural world that we inhabit. It is important to bear in mind that most of the practices of capitalism are premised on the profit motive, full of competitive individualism and corporate power, which have resulted in environmental destruction (Hollow, 2018a). These practices have been prevalent since the start of the industrial revolution with coalburning machines and the creation of petrolburning engines in vehicles by humans that largely produce toxic or non-healthy smokes.

The by-products of economic growth have a substantial possibility to drive us swiftly down the collapse of the ecological path. Nevertheless, humans are rewarded with GDP growth and profit accumulations.

Therefore, Hollo (2018a, 2018b) and Ostrom (1990) have proposed another kind of new political "common sense" to ride over capitalism. The existing form of capitalism has faced the cultural hegemony issue of a legitimacy crisis. Hence, civil societies are strongly urged to participate in political decision making (Brinkley, 2020). This new common sense is 
known as "ecological democracy", which is grounded in the seminal work of Ostrom (1990), classical works of Karl Marx and Henry David Thoreau and spinning back through history and beyond in the wisdom of indigenous peoples and the practices of the commons (Pascoe, 2014).

The commons' characteristics embedded in ecological democracy were described by Hollo (2018b), Niemeyer (2020), Pascoe (2014) and Schlosberg et al. (2019) as:

i. A radical green political vision of deep interconnection, interdependence and resilient in diversity;

ii. For people to find their own way together in synchronization with the planet;

iii. It rejects capitalism's hyper-individualism, growth fetish and celebration of greed;

iv. It is beyond socialism while proudly being of the left;

v. It is intrinsically intersectional and embedded in nature; and

vi. It can be regarded as a jig-sawed mutualism, where people have rights and obligations for specific pieces of the jigsaw but they are confined to operate their piece so that it adds to rather than reduces their neighbors' pieces and lessens the notable value of the land.
Ecological politics, viewed from the standpoint of socialism as regards to interconnected diversity, should be grounded in participatory democratic processes and puts equity, universalism, and pluralism at its core (Hollo, 2018a; Niemeyer, 2020). Several deeper participatory models have been proposed, such as proactive local planning, participatory budgeting, institutionalized citizens' assemblies, citizen-run sharing and repairing spaces, and cooperatives (Hollo, 2018b; Peters, 2017). In smart urbanisation development, one of the emphases is on citizen centricity which promotes participatory democracy and citizenship; it is this aspect that has gradually gained the attention of scholars (Berntzen et al., 2016; Cardullo \& Kitchin, 2018; Castelnovo et al., 2015; Lee \& Lee, 2014; Lim et al., 2018).

European practices include "do-cracy", which has been applied by the government of the Netherlands (government.nl, 2018), Fab City (Diez, 2016; Diez \& Posada, 2013), Barcelona, En Comu and London's Participatory City project (Hollo, 2018b). Under this "citizen centricity smart urbanisation" concept, the researchers see the opportunity and importance of "tuning" the over-focus on human prosperity under capitalism to emphasizing the natural environment and "commons" under ecological democracy. The researchers have summarized the characteristics of capitalism and ecological democracy in Table 3 below.

Table 3: Characteristics of capitalism and ecological democracy

\begin{tabular}{ll}
\hline \multicolumn{1}{c}{ Capitalism/ Liberal Democracy } & \multicolumn{1}{c}{ Ecological Democracy } \\
\hline Dominant and hegemony (of power and culture) & $\begin{array}{l}\text { Alternative, green politics and uphold the concept of } \\
\text { commons } \\
\text { Interconnected diversity and embed participatory } \\
\text { processes in institutions }\end{array}$ \\
$\begin{array}{l}\text { Alienation \& disconnection } \\
\begin{array}{l}\text { Untersectional politics \& understand inequalities } \\
\text { choice) }\end{array}\end{array}$ \\
$\begin{array}{l}\text { Treat nature as an inexhaustible resource to be } \\
\text { endlessly abused }\end{array}$ & $\begin{array}{l}\text { Humanity has no future unless one stops plundering } \\
\text { nature, treasure the sea \& wildlife }\end{array}$ \\
\hline
\end{tabular}

Sources: Berge and Laerhoven (2011), Hollo (2018b) and Ostrom (1990) 


\section{Smart Urbanisation, Sustainable Development and Politics in Malaysia}

Smart city development has some advantages as people throughout the world are interested in how sustainable targets can be achieved with the help of "ICT smartness" (Ahvenniemi et al., 2017). In Malaysia, the trend of smart urbanisation started in the central region of Peninsular Malaysia following the declaration by the government of the Multimedia Super Corridor and the development of intelligent cities in Cyberjaya and Putrajaya in the mid1990s.

The Seventh Malaysia Plan (1996-2000) has also adopted the sustainability concept propagated by the United Nations. Recently, the state of Selangor has launched the Smart State Vision 2025 and thus leading the country's smart urbanisation development (SSDU, 2016). Besides Cyberjaya, other cities including Petaling Jaya have also embarked on the smart city journey, which includes building a smart command control center (Norhayati Umor, 2017).

As for the smart development trend in the northern region of Peninsular Malaysia, the Kulim High-tech Park, in the state of Kedah was established with the assistance of the Japanese government and Japan International Cooperation Agency industrial counterparts (Lim, 2005) at the end of the 1990s. Besides Kedah, recently, the state of Penang has launched Smart Penang 2030 with the theme of "creating a familyfocused green and smart state that inspires the nation" (Tan, 2019). This political decision has stimulated the development of Penang Island through projects such as the Penang South Reclamation project (PSR) and the construction of the Pan Island Link 1 (PIL1) (Wong, 2019).

In the early 2000s in the southern region, the Iskandar Malaysia Development Corridor in the state of Johor had focused on the low carbon city and society framework (Ho et al., 2013). It was declared as Iskandar Malaysia Smart City in the year 2012 by the Sixth Prime Minister, Najib Razak (IRDA, 2017; Joeman,
2013). Cyberjaya also caught the government's attention and was restructured based on the Smart and Low Carbon City framework in the year 2017 (APUDG \& MPSp, 2017; Bernama, 2017). Besides Iskandar, other cities are also being aimed to be developed, such as Pengerang as a smart city (Bernama 2020), Seri Alam as a "smart city of knowledge" (Nordin, 2020) and Pasir Gudang as a low carbon society and green smart city (Hamidi, 2015).

The former Menteri Besar of Johor, Datuk Dr Sahruddin Jamal, said one of the key features of smart cities is the integration of technology into services that would generally improve public safety and their quality of life in addition to tackling the pollution issue (Nordin, 2020; The Star, 2019). These include 5G technology networks, cashless communities, efficient public transport, energy-efficient buildings, efficient water treatment and smart waste management (Nordin, 2020).

This restructuring has moved from the intelligent to the smart concept following the implementation of the Eleventh Malaysia Plan (2016-2020), where for the first time in the history of Malaysia, the "smart city initiative" is stated as a strategy in developing a knowledgebased economy (Malaysia, 2015). In September 2018, the top-down Malaysia Smart City Framework (MSCF) was launched to provide guidance for the development of national smart cities and bridge the gap among government agencies across different states (KPKT, 2019; Loo, 2019).

Five pilot city projects have been carried out under this framework, namely Kulim, Kedah (northern region), Kuala Lumpur (central region), Johor Bahru, Johor (southern region), Kuching (Sarawak) and Kota Kinabalu (Sabah).

Two weeks after the launch of the MSCF, the top-down policy of Shared Prosperity Vision 2030 (SPV 2030) was launched by the Seventh Prime Minister, Tun Mahathir Mohamad, in continuing the target of Vision 2020 to achieve a developed nation status (Aliran, 2019; Malaysia, 2019). The researchers 
noticed that the focus of SPV 2030 is primarily on economic growth and it avoids mentioning nationwide smart development. Tun Mahathir said the government's new SPV 2030, which aims to bridge the gaps in income and wealth between economic classes, ethnic groups and geographical territories, is in line with the SDGs (Augustin, 2019). Tun Mahathir added that "Malaysia will try its best to achieve the sustainable goals, although we have a need to do certain things which may cause a lot of problems for the environment" (Mansor, 2019).

The first researcher joined the focus group discussion in drafting the MSCF and noticed that the stakeholders (mostly government officers) were still focused on building the ICT infrastructure while ignoring the social participatory processes, participatory governance and the protection of the environment.

The researchers observed a gap where the stakeholders ignored and separated the smart and the sustainable city concepts. However, according to scholars, sustainable cities have served a bigger realm of development and a smart city is considered as a new or small part of a sustainable city (Ahvenniemi et al., 2017; Jong et al., 2015). However, sustainable cities do not necessarily include the smart concept in their planning. Recent trends have seen a new emerging concept known as smart sustainable cities (Bibri, 2018; Hojer \& Wangel, 2015; ITU, 2015) or sustainable smart cities (Madakam \& Ramaswamy, 2016; Qatar, 2014).

Thus, to ignore the environmental protection in the MSCF could lead to worsening environmental deterioration and continued upholding of (neo)liberal capitalism. Although Malaysia has adopted the elements of liberalism since the establishment of the Tanah Melayu Federal Constitution 1957 by the Reid Commission (A'zmi, 2016), the government should be aware that its natural resources such as sand, land and petroleum are limited and should not be freely exploited without control.

Additionally, despite being guided by the National Physical Plan, political leaders often make a "no" decision regarding the environment and social impacts (Annuar, 2019). In other words, if leaders insist on upholding capitalism, one can foresee that ecological democracies will remain a myth. Smart cities' ICT solutions have been proven effective in garnering collective decision making and monitoring urban systems and the environment (Dohler et al., 2013; White, 2016). It all depends on the focus of the leaders and awareness of the citizens in deciding the politics of development, whether to prioritize the vision of human prosperity or to uphold human rights and protect the planet for current and future generations.

\section{Methodology}

This study applied the approach of exploratory multiple case study analysis (Yin, 2018) in examining empirical examples concerning stakeholder partnerships and environmental cases in smart states/cities in Malaysia. The case study approach is deemed relevant upon fulfilling three conditions: a) the main research questions revolve around the how and why questions; b) the researcher has little or no control over the behavioural events and; c) the research focus is on contemporary events or phenomena (Yin, 2018, p. 32).

The application of the case study approach in this paper is intended to demonstrate the rule of the game of the actors involved especially between state (the Malaysian Government), corporations, politicians and local people as to how they react, respond and shape the smart city and environmental discourse. The selected six cases to be studied - the multiple case study enhance, strengthen and heighten the research findings as opposed to a single case study (Yin, 2018, p. 58). The case studies presented in this paper were obtained from site observations and secondary sources, aimed at demonstrating the role of political ideology in shaping the smart city discourse in Malaysia. The researchers make use of multiple case/data sources to provide corroborating evidence and triangulation to the objective studied (Creswell \& Poth, 2018).

Corroborating evidence through of multiple sources has been achieved since this 
study is a preliminary study to explore the politics of smart urbanisation, information and data gathered from stakeholders' documents are particularly important to be analyzed in terms of understanding the views from different stakeholders' perspectives (Marrone \& Hammerle, 2018). Online searches were performed, involving document/content analysis, in order to obtain the different stakeholders' views.

First, the researchers selected appropriate keywords such as smart urbanisation/city, sustainable development, SDGs, politics, partnership, environment and their synonyms. To assist in the search process, the researchers used Boolean operators, namely "AND" and "OR", or wildcard asterisks $(*)$ to allow for plurals and other word suffixes.

Second, the databases used in this study are Google Scholars, Web of Science (WoS) and Scopus. Upon the completion of the database search, the researchers performed searches of direct journals that typically contained the term "smart city." The selected journals are Cities, Planning Malaysia, European Journal of Futures Research, Urban Research and Practice, Environment and Planning: Politics \& Space, Social Science Computer Review, Journal of Cleaner Production, IT-Information Technology, IEEE Communications Magazine, Journals of Development Management and Communication, Cambridge Journal of Regions, Economy and Society, Habitat International and Urban Studies.

Third, to widen the search, the researchers included newspaper searches of Malaysiakini, Eco-Business, Free Malaysia Today and The Online Citizen. The reference list of each of the previously identified articles was examined to see if it met the inclusion criteria. The articles obtained were considered final after the search for articles reached a saturation point.

In the analysis and coding stage, the researchers examined all the final articles for their relevancy by screening the abstracts and classifying the articles into three broad categories. These categories are: i) Remove the articles that clearly did not meet the inclusion criteria, ii) When it was unclear whether the articles met the inclusion criteria, the full articles must be read and iii) Read the full articles that were likely to meet the inclusion criteria. The selected articles were thoroughly read by the researchers and then coded and analysed. The analysis included a) comparing the characteristics of capitalism and ecological democracy. In this comparison, the following attributes were used - general meaning, the role of market/corporation, the role of state/government/public administrator and the role of a citizen (refer Appendix); b) identifying the advantages and disadvantages of politics to smart urbanisation development in the SDGs era.

During this process, the following attributes were used - the type of politics, its pros and its cons; and c) identifying the development cases related to smart urbanisation/cities in Malaysia. In this identification analysis, the researchers used the following attributes - stakeholder partnerships and the environment.

\section{Findings}

This section provides a discussion of the findings from the six cases in Malaysia against the background of continuous smart urbanisation and the launch of the SDGs locally. The first two cases are related to multi-stakeholder partnerships, which are stressed in the 17th SDG, while the other four cases are related to environmental destruction vs. GDP growth.

\section{Case 1: Petaling Jaya City Council's Smart Command Centre}

In forming a smart city partnership with the private sector, the Malaysian government is similar to other Asian countries in that the government tends to partner with the private technology sector. For example, the Smart Command Centre of Petaling Jaya City Council (MBPJ) involves a partnership with local ICT companies, namely, MNJ Teras Sdn Bhd (MNJ) and Celcom Axiata Bhd. Through site observation and an interview with the person in charge of MNJ, the researchers found that 
the software development company secured a contract to provide GIS-related applications and smart city solutions to support the dashboard operations of Petaling Jaya Smart Centre. Meanwhile, Celcom Axiata's 5G technology is used to increase the effectiveness of security and monitoring through CCTV and traffic surveillance, among others (Ch'ng, 2020) (refer Figure 2).

PJ Smart Centre, built with a total cost of RM9 million, began operating in March 2020 and allows the public to access the center with permission (Ch'ng, 2020). However, there is no mention of any plans for civil society partnership in its operation or technological upgrading matters.

Under the hegemonic capitalism politics, there is little evidence that the Malaysia Smart City Framework (KPKT, 2019) includes civil society engagement. The researchers observed that it is not a priority, as the emphasis is always on the development infrastructure with "strategic" partnerships with the private technology sector.

On the ground, for example in the case of MBPJ, strategic partnerships with businesses have always outnumbered engagement with civil societies (Table 4). Furthermore, in most cases, the civil societies act as beneficiaries rather than providing technical support to the city council (MBPJ \& UPUM, 2016).

\section{Case 2: Forums for Multi-stakeholder Partnerships}

In recent forums and movements such as the 9th World Urban Forum (WUF) in Kuala Lumpur 2018, Malaysia Urban Forum 2019, 7th AsiaPacific Urban Forum 2019 in Penang and Malaysia SDG Summit 2019 in KLCC, efforts by the federal, state and local governments are evident in disseminating the 17 th SDG - multistakeholder partnerships -across various sectors.
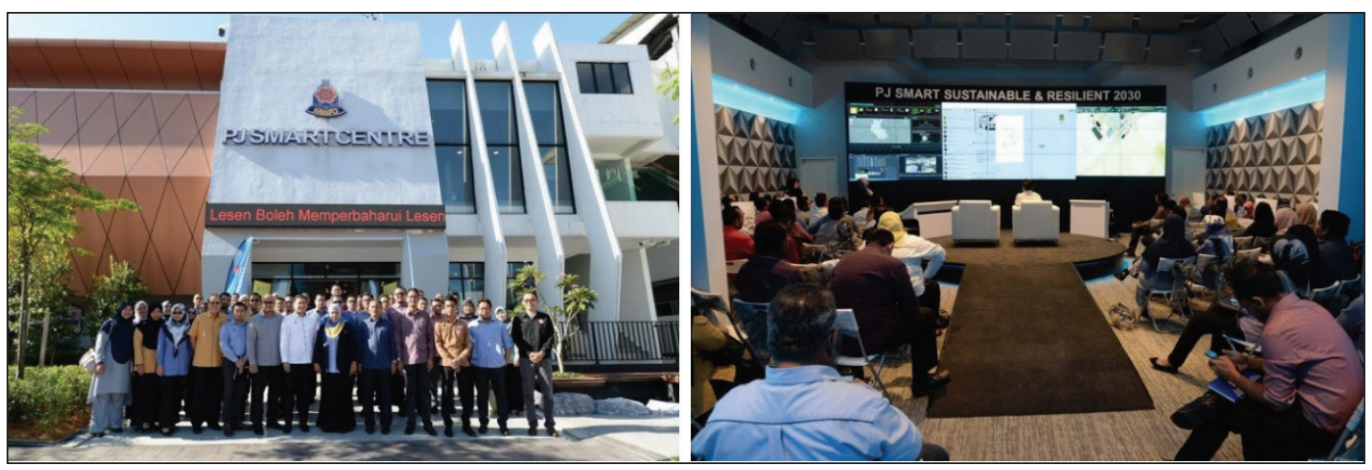

Figure 2: Petaling Jaya Smart Centre

Source: MBPJ (2020)

Table 4: Collaborative stakeholders in Petaling Jaya City Council (MBPJ)

\begin{tabular}{lclc}
\hline $\begin{array}{c}\text { Profile of Collaborative } \\
\text { Stakeholders }\end{array}$ & $\begin{array}{c}\text { Cases } \\
\text { (in number) }\end{array}$ & $\begin{array}{c}\text { Collaborative Stakeholder's } \\
\text { Sectors of Interest }\end{array}$ & $\begin{array}{c}\text { Cases } \\
\text { (in \%) }\end{array}$ \\
\hline Businesses & 368 & Environment & 55 \\
Civil society & 23 & Social & 10 \\
Institutions & 30 & Education & 20 \\
Clubs & 107 & Vocation & 5 \\
Individuals & 1,297 & Empowerment & 10 \\
\hline
\end{tabular}

Source: MBPJ (2019) 
Urbanice Malaysia, an urban think tank under the purview of the Ministry of Housing and Local Government (KPKT), has collaborated with universities in Malaysia to promote the Malaysia 100 Years Cities Programme (M100YC) (Azmizam, 2018). As noted by Yeoh (2019), partnering with civil society organisations (CSOs) will be a vital aspect of achieving the SDGs. The Dewan Rakyat Speaker, Tan Sri Mohamad Ariff Md Yusof, should be commended for getting the Parliament to approve the establishment of the All-Party Parliamentary Group on SDGs. This initiative will nudge the Members of Parliament (MPs) to work with CSOs on SDGs projects in their respective constituencies.

However, one area which is lacking is the business commitment to and support for the SDGs (Yeoh, 2019). While many companies are already carrying out various CSR programmes, these are insufficient to make a difference. Furthermore, achieving the SDGs by 2030 requires massive new investments amounting to US $\$ 1.5$ trillion. Hence, the private sector needs to play a bigger role and help to provide the needed financing to achieve the SDGs.

According to to Azmizam (2018), Malaysia will forge ahead by strengthening partnerships among various stakeholders in the country's quest to achieve the SDGs in the next 20 years and beyond. However, a solid national sustainability policy on multi-stakeholder partnerships enforced by law has yet to be seen. The first researcher had organised and acted as the forum moderator of a side event during the WUF which involved academicians and industrial stakeholders to discuss the topic of citizen participation in a smart city. From the experience, the first researcher noticed that such an international platform could serve as a "one-time social meet type of partnership," yet real cooperation among stakeholders has not materialised. Thus, these forums and movements could be one kind of tokenism (Arnstein, 1969) by the power holders. The actual emphasis on the rights of (smart city) citizens (Foth et al., 2015; Ganguly, 2015; Marsal-Llacuna, 2015; Willis,
2019) are still subjugated and is less likely to be legally enforced hampering the achievement of SDGs in Malaysia.

\section{Case 3: Plastic waste import from first world countries}

The importation of "recycling" plastic waste from first world countries such as Australia, the United Kingdom and New Zealand into Malaysia for burning and dumping has been partly blamed on the government who has allowed such disgraceful acts due to lax enforcement of Approved Permits (APs) and regulations (Little, 2019). Malaysia has become the largest "dumping site" since China started refusing to accept international rubbish (Oon, 2018a).

The question that is often asked is if the smart city ICT solutions can solve the issue of plastic rubbish, does it mean that Malaysia should continuously import such rubbish in return for RM15 for every tonne of waste imported (Oon, 2018b)?

Apart from that, recently, many cases of illegally imported plastic waste have been discovered in Selangor, Kedah and Johor and recycling factories have also been found to be dirty, smelly and degrade residents' quality of life.

Actions taken by Yeoh Bee Yin, the former Energy, Technology, Science, Climate Change and Environment Minister in closing down more than 100 illegal factories was commendable (Bernama, 2019b), but that could be just the cornerstone of the whole story of curbing such illegal acts in the long term.

\section{Case 4: Kim River Pollution, Johor}

In the real world, considerable destruction of the environment happens due to the acts of irresponsible parties and these perpetrators are not afraid to break the law. The recent incident of serious pollution in Kim River, Pasir Gudang area caused by illegal chemical dumping (Soo, 2019) is one of many. The fact is that the criminals are not afraid of the law, knowing that 
punishments for wrong-doers are very negligible (Tan, 2019).

The punishments under Section 34B of the Environmental Quality Act 1974 in connection with contamination provide for a maximum jail sentence of five years and a maximum fine of RM 500,000 if convicted. These low levels of punishment were admitted by the Seventh Prime Minister, Tun Mahathir Mohamad, as relatively lenient and might need to be reviewed (Bernama, 2019a).

Therefore, the solution could be amending the laws related to environmental pollution. Without a stronger form of punishment, such irresponsible crimes will keep occurring and social and ecological democracies will be reduced. Therefore, as a safeguard, countries leaders need to act on amending the relevant laws. They should also form partnerships with citizens as co-producers of real, sustainable development countrywide.

The former minister, Yeoh Bee Yin, mentioned that the government did not want incidents like the Kim River pollution to occur again and had thought of ways to increase industrial monitoring in the area, such as by investing RM 6.9 million in a warning system for air pollution in Pasir Gudang.

This system is equipped with an alarm for detecting harmful pollutants in the air that can alert the enforcement officers of the Department of Environment (DoE) to take immediate action in the event of an air pollution incident (Tan, 2020). For example, monitoring by drones has also been implemented since October 23, 2019 , to detect any contaminants and sources of contamination faster so that preventative measures can be taken early.

\section{Case 5: Sand Mining and Coastal Erosion}

Malaysia is a hotspot for illegal sand mining as other countries like Vietnam, Indonesia and Cambodia have banned exports due to pressure from environmental groups and local fishermen. Despite a previous ban on sand export, Malaysia remained in the top ten list of world export for sand from 2010 to 2014 (Chua, 2019).

In the name of "development", capitalistminded leaders in Malaysia have concrete economic figures to convince the public to exploit planetary resources, such as the sand mining cases that happened in the states of Johor (in Muar, Parit Jawa, Pengerang [refer Figure 3], Pulau Merabong aka the Forest City and Pasir Gudang) and Perak (Khairul Anwar, 2019).

Illegal sand mining activities were also perpetrated in the Penang South Reclamation (PSR) project. It has been noted that sand is the second most exploited natural resource in the world after fresh water. The industry is plagued with corruption, mafia activities and criminal intimidation (Chua, 2019).

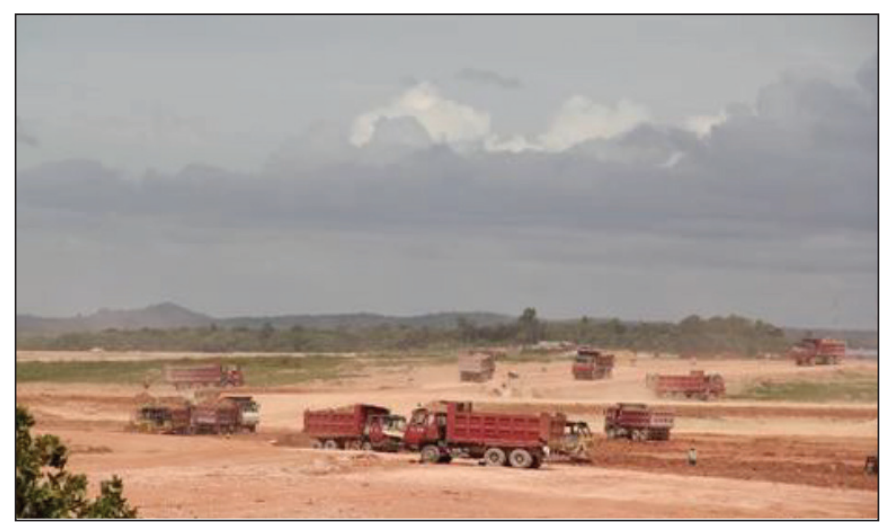

Figure 3: Sand mining activities in Pengerang, Johor Source: Chua (2019) 
Keizrul Abdullah (1999) highlighted that uncontrolled sand mining activity was the main problem in coastal environmental management. Thus, since July 2017, the federal government has begun issuing permits for marine sand mining in the waters of Parit Jawa, Johor, as per the Continental Shelf Act 1966. According to Chua (2019), up to 40 permits have been issued to allow the exportation of marine sand to Singapore. With the price of sand ranging from RM 200 to RM 600 per ton and 40 ships each taking over 1000 tonnes per day, the potential profit from the mines within 180 days would be about RM1.44 billion to RM4.32 billion.

Since the commencement of sand mining operation in Parit Jawa, which is a known natural heritage and mangrove swamp, many fishermen have made police reports due to the loss of their nets, fish trap and damaged equipment caused by dredging activities.

However, there has been no news of action or compensation forthcoming from the relevant authorities (Chua, 2019). Due to the low transparency in governance, one also does not know whether such activities follow the sustainable management guidelines proposed by experts such as Zamali and Lee (1991) and Abdullah (1999). The researchers view that both legal and illegal sand mining activities are causing serious destruction of the near shore marine environment in the long term because larger waves are reaching the shoreline, thus increasing the sediment transport rate that often leads to coastal erosion problems. Meanwhile, the benthic assemblages only return after four years and can only be attained if the topography and original sediment composition are restored (Chua, 2019).

Case 6: Penang South Reclamation (PSR) Project and the Building of the Pan Island Link 1 (PIL1) Highway vs. Penang Smart State 2030 Vision

The Penang South Reclamation (PSR) project and the building of the Pan Island Link 1 (PIL1) highway have adverse environmental impacts. Do Penangites really need man-made islands and highways to realize the vision of Penang 2030 - a family-focused, green and smart state dream? The term "smart" signifies the state's efforts to embrace the digital revolution for Penangites (Johari, 2019), albeit with a low reputation in protecting nature.

Despite the government's insistence to proceed with the PSR project which would see the creation of three manmade islands measuring some 1,800 ha (Dermawan, 2019b) and the PIL1 project upon gaining a two-year approval via the Environmental Impact Assessment reports (Dermawan, 2019c), voices from the public, protest memos from fishermen and open letters from non-governmental organizations (NGOs) kept appearing (Annuar, 2019) (refer Figure 4).

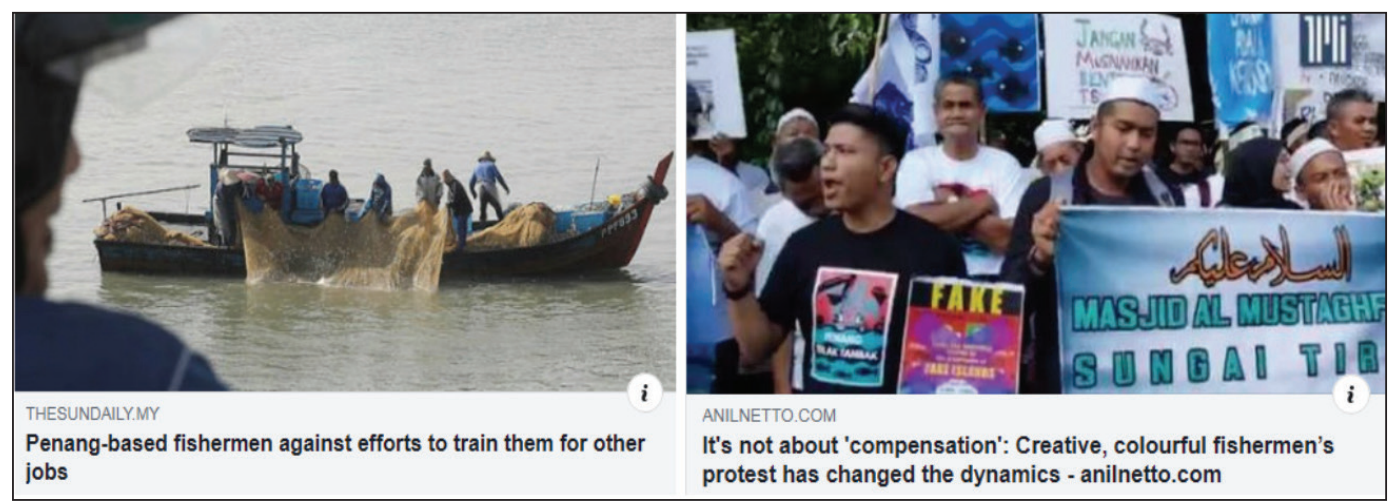

Figure 4: Voices from the public in protesting the Penang South Reclamations project Source: Mcintyre (2019) and Netto (2019) 
For example, the chairman of Penang Fishermen Association, Nazri Ahmad, said they were disappointed with the "arrogance culture" portrayed by the Penang state government, "We are here to personally meet state leaders to voice our laments to them. We want to tell them personally why we are against the project. Instead, we were met by a representative outside the building. This is most disappointing. In Parliament, we even managed to meet several Cabinet ministers."

Nazri Ahmad said they had spoken out against the reclamation project since 2015 but their concerns fell on deaf ears, "There should be a form of cooperation between the state government and us on this issue, but such cooperation is not in sight" (Dermawan, 2019a). Meanwhile, the president of the Consumers Association of Penang (CAP), Mohideen Abdul Kader, urged all Malaysians to reject the reclamation (Dermawan, 2019a).

The project is expected to generate RM70 billion, of which RM46 billion will be used to fund the Penang Transport Master Plan (Trisha, 2019). Seeing the conflict between development and local discontentment, on July 13, 2019, the Pakatan Keadilan Rakyat (PKR) leader Anwar Ibrahim had turun padang (met the people on the ground) and held dialogues with the nelayan (fishermen). However, on July 25, 2019, Anwar told the media that he supported the Penang government's intention to seek federal funding for the PSR project, hinting at his support for the PSR project to proceed (Figure 5).

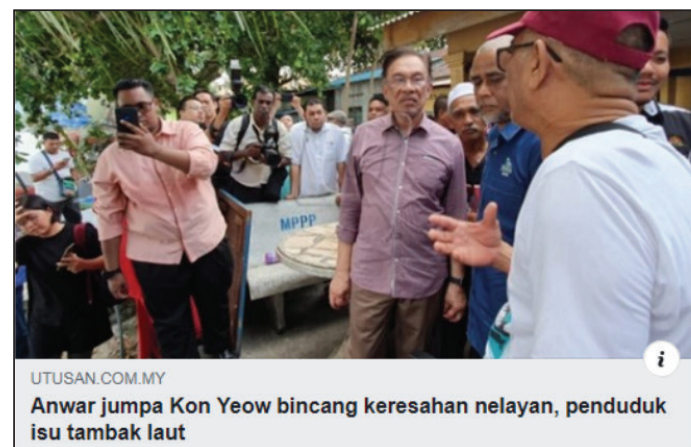

\section{Discussion}

Based on the findings above, the researchers have identified several challenges. The six cases demonstrate that the leaders of the country are strong advocates of capitalism. Tang (2018) rightly pointed out that Malaysians voted the Pakatan Harapan government not because of green or social rights issues but with the hope that the then newly-elected government would address the rising living costs and stamp out institutional corruption.

Concerns about Tun Mahathir's previous record (during his 1981-2003 term as the fourth Prime Minister) and his priorities of tackling environmental and economic issues, Tun tended to choose the latter and sacrifice the former (Tang, 2018).

Further, in the recent SDG Summit Leaders Dialogue at the UN headquarters in September 2019, Tun mentioned that Malaysia would strive to achieve the SDGs, but he hinted this would be at the expense of the environment (Mansor, 2019).

The findings of the said six cases could be handled better through genuine instead of tokenism civic partnerships or avoided altogether by salvaging the natural environment rather than causing destruction. However, to do so, the leaders need to adopt ecological and democratic principles such as prioritising genuine citizen participation, matching indigenous social systems and ceasing from plundering nature for humans' selfish reasons (refer Appendix).

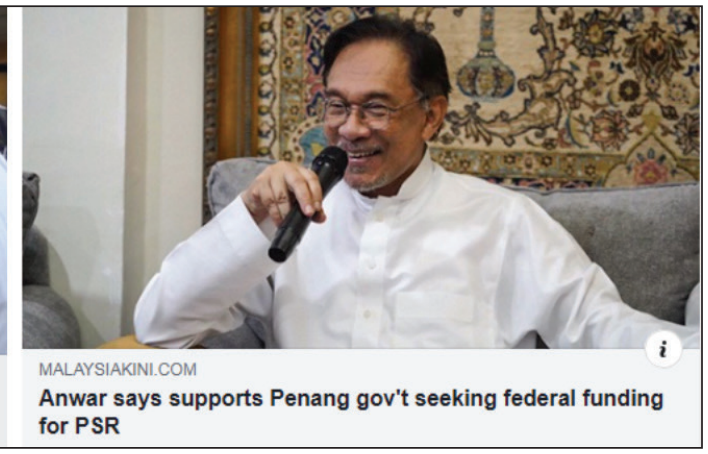

Figure 5: Responses of a political leader on the PSR project Source: Khairul Anwar (2019), Syajaratulhada (2020) 
The authors assert that with continuous trust and encouragement for concerted civic actions of the commons, the leaders would be able to transform the nation, or the world based on respect for the vital cycles of nature and social well-being.

For the issue of multi-stakeholder participation, it has been frequently highlighted by scholars (e.g., Asmawi et al., 2015; Chan, 2005; Patunru \& Haryoko, 2015) and institutions, such as the UN and Urbanice Malaysia. However, these civic involvements are clearly not the practice of capitalism politics. Practices such as prioritizing high and advanced technologies by corporates rather than bottomup low technology solutions by local societies as well as "one-off forums and workshops on partnerships" as presented in the findings are the "unspoken norms" of the smart urbanisation practices. The proposed new norms of active multi-stakeholder partnerships are still scarce in practice, thus resulting in the tokenism type of "sustainable governance" or "sustainable management" suggestions/solutions where the top leaders are delegating limited or minimal decision-making power to the locals.

That being said, corporations are created to make profits and transnational civil society groups are no match to their resources, technologies and organizing abilities (Jalaluddin et al., 2019; Maboloc, 2016). Thus, it all depends on the politics of leaders as to whether they want to step in and persist in cultivating civil societies as co-producers under smart urbanisation.

For the issue of environmental destruction, cases of importation of plastic waste, river pollution and sand mining demonstrate that economic gains and growth figures are always the priority of capitalism leaders. Examples provided in the findings hint that it might be the politics of leaders to show that they care or are listening to the voices of affected locals. In reality, they know the strategies to placate the locals at the right time and also predict that people tend to forget the long-term impacts of environmental deterioration as compared to their utmost concern on monetary compensation.
Such capitalism politics are clearly driven by economic figures while tokenizing the voice of affected locals. If the state is to be developed based on the cost-benefit analysis and the GDP growth perspective (the "DNA" of capitalist politics), then public outcry will remain subjugated. Nevertheless, to rethink the development of a smart state/city from the perspective of alternative politics, one has to consider the political situation, the competencies of people and the community, including their level of maturity and the nuances of power and institutional influences (Maboloc, 2016).

Therefore, how is it possible for the SDGs to be achieved in 2030 under such strong world hegemony of the institutional and cultural capitalism system? It is true that both political leaders and market corporates are comfortable and surviving well under capitalism politics. The persistent issue is whether the power holders will be willing to go against the stream, gradually allowing participatory practices to prevail and finally abandoning capitalist politics and adopting ecological democracy.

Capitalism is eating itself (Hollo, 2018a) because alarming global issues such as climate change, peace and genocide of indigenous people can be solved only under the alternative realm of ecological democracy (Gomes, 2018). These global problems are closely related to Malaysia, even though it may not be obvious at the moment.

As discussed in the literature, it could be possible that the current SDGs are set in the wrong direction by the capitalist-thinking leaders. Although the SDGs are backed by the Millennium Development Goals (MDGs) (UN, 2019), the decision to not make the save the planet vision as a priority is a sign and symptom of the environmental deterioration prevailing in Malaysia. If the world is concerned with ecological democracy under the political ecology lens (Bryant, 2015; Perreault et al., 2015), then the SDGs need to be genuinely revamped with the priority set as the protection of nature. 
The researchers have compared the advantages and disadvantages of the politics of capitalism and ecological democracy to smart urbanisation, which are summarised in Table 5 below.

The researchers understand that it may not be easy or perfect for leaders to adopt the politics of ecological democracy and abandon capitalism politics totally, as both have their strengths and weaknesses. However, seeing the urgency of environmental deteriorations and tokenism type of multi-stakeholder partnerships as discussed in the findings, along with having the environmental ethics in mind, the far-sighted Malaysian leaders should consider rolling out the alternative ecological democracy by stages. This determination must be shown in the coming top-down policies, including the 12th Malaysia Plan and beyond.
Therefore, in this paper, the researchers would like to call for the prioritization of the SDGs that truly give precedence to nature, embed nature, that jump and think out of the box of capitalism and embrace the politics of ecological democracy. In the realm of such green politics, smart urbanisation will follow suit towards establishing the quality of life for humans that should never sacrifice nature.

Fundamentally, nature is us and we are nature. The UN's Sustainable Development Solutions Network (SDSN) director, Jeffrey Sachs, suggested that "The social-market philosophy of a mixed economy that balances the market, social justice and green economy is the route to the SDGs." (Abdul Hamid, 2018).

Table 5: Advantages and disadvantages of politics to smart urbanisation

\begin{tabular}{|c|c|c|}
\hline Politics & Pros & Cons \\
\hline \multirow[t]{9}{*}{ Capitalism } & - Supported by national legal laws; & - A democratic deficit; \\
\hline & • Dominant and practiced by leaders; & - Ignore the social rights factor; \\
\hline & $\begin{array}{l}\text { compatible with the market-led } \\
\text { (corporate-led), state support, citizen }\end{array}$ & - Constrain citizens' role as customers; \\
\hline & as consumer notions of wealth & - Undermining the power of voting; \\
\hline & accumulation; & - Criminalizing and delegitimizing protests; \\
\hline & - Human prosperity vision; & - Advocacy while welcoming the \\
\hline & - Greatest human freedom; & participation of corporations; \\
\hline & - Multiple choices in hand; and & $\begin{array}{l}\text { - Ignore human and environment relationship; } \\
\text { and }\end{array}$ \\
\hline & $\begin{array}{l}\text { - Quality of human living with the help of } \\
\text { ICT solutions. }\end{array}$ & $\begin{array}{l}\text { - Humankind has full rights in exploiting the } \\
\text { planet's resources. }\end{array}$ \\
\hline \multirow[t]{5}{*}{$\begin{array}{l}\text { Ecological } \\
\text { democracy }\end{array}$} & $\begin{array}{l}\text { - Highlighting the concept of the commons } \\
\text { - share, protect and committed to future } \\
\text { generations: }\end{array}$ & $\begin{array}{l}\text { - Anti-capitalism thinking where profits for } \\
\text { humans is subsided; }\end{array}$ \\
\hline & $\begin{array}{l}\text { generations; } \\
\text { - Human and environment relationship is } \\
\text { of primary importance as to evade urban }\end{array}$ & $\begin{array}{l}\text { - Anti-development where GDP growth is } \\
\text { put in second priority in consideration of } \\
\text { environmental issues; }\end{array}$ \\
\hline & ecocide; and & - Difficult to define and apply the commons \\
\hline & - International organizations and & concept; and \\
\hline & $\begin{array}{l}\text { movements have highlighted the urgency } \\
\text { of protecting the planet. }\end{array}$ & $\begin{array}{l}\text { - Difficult to satisfy human's greed on wealth } \\
\text { accumulations }\end{array}$ \\
\hline
\end{tabular}

Source: The researchers' compilation 


\section{Conclusion}

This study has contributed by underlining an alternative political ideology of ecological democracy, despite the dominance of capitalism, in order to enable smart urbanisation to achieve the SDGs. The advantages and disadvantages of each path, as discussed in this study, are among the factors that country leaders can consider for the legal adoption of such development under the lens of political ecology. As mentioned by the UN (2019), the fate of the SDGs is in the hand of country leaders.

Malaysians should be aware of how to exercise their voting power in selecting leaders who appreciate green eco-friendly, sustainable goals when developing a smart nation for current and future generations. Although ecological democracy is positioned as utopian politics, with environmental ethics in mind, leaders should implement it with caution without rejecting technologies and economic development. Exploration of other compatible ideas such as degrowth (Hanaček, et al., 2020 and sustainable development index (Hickel, 2020) would be timely.

As for the limitation of this study, the researchers focused on only two political paths. Future studies might be interested in exploring other paths, such as social democracy and the rights of conservative or communist ideologies, to enrich the body of literature.

\section{Acknowledgments}

This paper is an improved version from a paper presented in the $2^{\text {nd }}$ International Conference on Sustainable Development Goals (ICSDG 2019), 30-31 July, Penang.

\section{References}

A'zmi, A. A. (2016). Liberalisme dalam konteks asas pembinaan negara Malaysia. Malaysian Journal of Social Science, 1, 1-16.

Abdul Hamid, Z. (2018). Sustainable development goals: Are we on track?
Retrieved April 21, 2019, from https://www. might.org.my/sustainable-developmentgoals-are-we-on-track/

Abdullah, K. (1999). Malaysian coastal environment: Planning, development and management of the environment in preparation for the next millennium. Proceeding of the International Symposium and Exposition on Coastal Environment and Management: Challenges in the New Millennium. 13-15 October, 1999. Kuala Lumpur, Malaysia.

Ahvenniemi, H., Huovila, A., Pinto-seppä, I., \& Airaksinen, M. (2017). What are the differences between sustainable and smart cities? Cities, 60, 234-245.

AJM Planning and Urban Design Group \& Majlis Perbandaran Sepang (APUDG \& MPSp). (2017). Cyberjaya Smart Low Carbon City Action Plan 2025. Cyberjaya: AJM Planning and Urban Design Group \& Majlis Perbandaran Sepang.

Aliran. (2019). 'Shared Prosperity' - How different a vision? Retrieved October 19, 2019, from https://www.youtube.com/ watch? $\mathrm{v}=\mathrm{FAF} 64 \mathrm{NjIINw}$ or https://aliran. com/web-specials/shared-prosperity-howdifferent-a-vision/

Annuar, A. (2019). PM urged to reconsider Penang coastal reclamation project. Retrieved April 20, 2019, from https://www.malaymail.com/news/ malaysia/2019/04/19/pm-urged-toreconsider-penang-coastal-reclamationproject $/ 1744800$

Araya, D. (Ed.). (2015). Smart cities as democratic ecologies. New York \& London: Palgrave Macmillan.

Arnstein, S. R. (1969). A ladder of citizen participation. Journal of the American Institute of Planners, 35(4), 216-224.

Asmawi, M. Z., Mahamod, L. H., Mohamed, M. Z., \& Paiman, T. (2015). Sustainable governance in relation to the financial aspect in managing coastal areas: Malaysian 
experience. Planning Malaysia, XIII, 123138.

Augustin, R. (2019). Malaysia committed to sustainable development, says Dr M. Retrieved April 12, 2020, from https:// www.freemalaysiatoday.com/category/ nation/2019/11/06/malaysia-committed-tosustainable-development-says-dr-m/

Azmizam, A. R. (2018). Malaysia's perspective on multi-stakeholder partnership for sustainable local development. Presentation at the 7th UCLG ASPAC Congress on Innovation-Driven Development for Sustainable Cities 12-15 September 2018, Surabaya, Indonesia.

Bakar,A.A., Osman, M. M., Bachok, S., Ibrahim, M., \& Abdullah, M. F. (2016). Sustainable well-being: An empirical exploration on human needs and human interdependency. Planning Malaysia, XIV, 29-38.

Barrow, C. J. (2010). How is environmental conflict addressed by SIA? Environmental Impact Assessment Review, 30(5), 293-301.

Berge, E., \& Laerhoven, F. van. (2011). Editorial: Governing the commons for two decades: a complex story. International Journal of the Commons, 5(2), 160-187.

Bernama. (2017). Najib announces 11 projects, initiatives to turn Cyberjaya into smart city. Retrieved July 30, 2017, from http://www. themalaymailonline.com/malaysia/article/ najib-announces-11-projects-initiatives-toturn-cyberjaya-into-smart-city

Bernama. (2019a). Environmental Quality Act 1974 may be reviewed, says PM. Retrieved May 14,2019, from https://www.malaymail. com/news/malaysia/2019/03/14/ environmental-quality-act-1974-may-bereviewed-says-pm/1732779

Bernama. (2019b). Yeo: 100 illegal plastic waste recycling plants to be closed down. Retrieved April 21, 2019, from https:// www.malaysiakini.com/news/460673

Berntzen, L., Johannesen, M. R., \& Ødegård, A. (2016). A citizen-centric public sector: Why citizen centricity matters and how to obtain it. Proceedings of the 9th International Conference on AHPMTS, 14-20. Rome: IARIA.

Bibri, S. E. (2018). Backcasting in futures studies: A synthesized scholarly and planning approach to strategic smart sustainable city development. European Journal of Futures Research, 6(13), 1-27.

Bollier, D. (2014). Think like a commoner. Gabriola Island, BC: New Society Publishers.

Brinkley, C. (2020). Hardin's imagined tragedy is pig shit: A call for planning to recenter the commons. Planning Theory, 19(2), 127 -144 .

Bryant, R. L. (2015). The international handbook of political ecology. UK: Edward Elgar Publishing Limited.

Cardullo, P., \& Kitchin, R. (2018). Smart urbanism and smart citizenship: The neoliberal logic of 'citizen-focused' smart cities in Europe. Environment \& Planning C: Politics \& Space, 1-18. https://doi. org/10.31235/osf.io/xugb5

Castelnovo, W., Misuraca, G., \& Savoldelli, A. (2015). Smart cities governance: The need for a holistic approach to assessing urban participatory policy making. Social Science Computer Review, 34(6), 724-739.

Ch'ng, B. (2020). Smart centre comes into operation. Retrieved April 3, 2020, from https://www.thestar.com.my/metro/metronews/2020/03/17/smart-centre-comes-intooperation

Chan, N. W. (2005). Sustainable management of rivers in Malaysia: Involving all stakeholders. International Journal of River Basin Management, 3(3), 147-162.

Chua, W. B. (2019). The impact of marine sand mining in Johor. Retrieved April 20, 2019, from Malaysiakini.com website: https:// www.malaysiakini.com/letters/403574 
Creswell, J. W., \& Poth, C. N. (2018). Qualitative inquiry and research design (4th ed.). Thousand Oaks, CA: Sage.

de Jong, M., Joss, S., Schraven, D., Zhan, C., \& Weijnen, M. (2015). Sustainable-smartresilient-low carbon-eco-knowledge cities; making sense of a multitude of concepts promoting sustainable urbanization. Journal of Cleaner Production, 109, 25-38.

de Waal, M., \& Dignum, M. (2017). The citizen in the smart city. How the smart city could transform citizenship. IT-Information Technology, 59(6), 263-273.

Dente, B. (2014). Who decides? Actors and their resources. In B. Pernici, S. D. Torre, B. M. Colosimo, T. Faravelli, R. Paolucci, \& S. Piardi (Eds.), Understanding policy decisions (pp. 29-66). Milan: Springer.

Dermawan, A. (2019a). 1,000 fishermen hand protest memo to Penang govt over PSR project. Retrieved April 12, 2020, from https://www.nst.com.my/news/ nation/2019/11/535736/1000-fishermenhand-protest-memo-penang-govt-over-psrproject

Dermawan, A. (2019b). Chow insists Penang South Reclamation project good to go once 18 conditions are met. Retrieved April 21, 2019, from https://www.nst.com.my/ news/nation/2019/04/481024/chow-insistspenang-south-reclamation-project-goodgo-once-18-conditions

Dermawan, A. (2019c). Penang govt insists PIL 1 highway vital for development. Retrieved April 21, 2019, from https://www.nst. com.my/news/nation/2019/04/479987/ penang-govt-insists-pil-1-highway-vitaldevelopment

Diez, T. (2016). Fab City whitepaper: Locally productive, globally connected selfsufficient cities. Retrieved from https://fab. city/uploads/whitepaper.pdf

Diez, T., \& Posada, A. (2013). The Fab and the Smart City. The use of machines and technology for the city production by its citizens. Proceedings of the 7th International Conference on Tangible, Embedded and Embodied Interaction - TEI '13, 447-454.

Dohler, M., Ratti, C., Paraszczak, J., \& Falconer, G. (2013). Smart cities. IEEE Communications Magazine, 51(6), 70-71.

Dryzek, J. S. (2005). The politics of the earth: Environmental discourse (2nd ed.). New York: Oxford University Press.

Elkington, J. (1997). Cannibals with forks - The triple bottom line of 21st century business Cette. Oxford, UK: Capstone.

Fab City. (2018). Fab City global initiative: The Fab City commitment. Retrieved from https://fab.city/documents/Fab_City_ Commitment_2018.pdf

Forsyth, T. (2003). Critical political ecology: The politics of environmental science. USA: Routledge.

Foth, M., Brynskov, M., \& Ojala, T. (Eds.). (2015). Citizen's right to the digital city: Urban interfaces, activism, and placemaking. Singapore: Springer.

Ganguly, D. (2015). Exploring the idea of 'Development' in a neoliberal state: Do the poor have the right to 'smart' city. Journal of Development Management and Communication, II(3), 256-263.

Gomes, A. (2018). Lessons from the margin: Indigenous peace ecology. Organicom, 15(28), 149-166.

government.nl. (2018). Citizen participation. Retrieved November 29, 2018, from https:// www.government.nl/topics/active-citizens/ citizen-participation

Gururani, S., \& Vandergeest, P. (2014). Introduction: New Frontiers of Ecological Knowledge: Co-producing Knowledge and Governance in Asia. Conservation and Society, 12(4), 343-351.

Hamidi, I. (2015). UTM initiates 1st Pasir Gudang Low Carbon Society \& Green Smart City focus group discussion. 
Retrieved April 12, 2020, from https:// news.utm.my/2015/03/utm-initiates-1 stpasir-gudang-low-carbon-society-greensmart-city-focus-group-discussion/

Hanaček, K., Roy, B., Avila, S., \& Kallis, G. (2020). Ecological economics and degrowth: Proposing a future research agenda from the margins. Ecological Economics, 169(September 2019), 106495. https://doi. org/10.1016/j.ecolecon.2019.106495

Hickel, J. (2020). The sustainable development index: Measuring the ecological efficiency of human development in the anthropocene. Ecological Economics, 167(106331). https://doi.org/10.1016/j. ecolecon.2019.05.011

Ho, C. S., Matsuoka, Y., Simson, J., \& Gomi, K. (2013). Low carbon urban development strategy in Malaysia - The case of Iskandar Malaysia development corridor. Habitat International, 37, 43-51. https://doi. org/10.1016/j.habitatint.2011.12.018

Ho, E. (2017). Smart subjects for a Smart Nation? Governing (smart) mentalities in Singapore. Urban Studies, 54(13), 31013118.

Hojer, M., \& Wangel, J. (2015). Smart sustainable cities: Definition and challenges. In L. M. Hilty \& B. Aebischer (Eds.), ICT innovations for sustainability. Advances in Intelligent Systems and Computing vol 310 (pp. 333-349). Cham: Springer.

Hollands, R. G. (2015). Critical interventions into the corporate smart city. Cambridge Journal of Regions, Economy and Society, 8(1), 61-77.

Hollands, R. G. (2016). Beyod the corporate smart city? Glimpses of other possibilities of smartness. In S. Marvin, A. Luque-Ayala, \& C. McFarlane (Eds.), Smart urbanism: Utopian vision or false dawn? (pp. 168184). London: Routledge.

Hollo, T. (2018a). Towards ecological democracy - Part 1. Retrieved February
26, 2019, from https://greenagenda.org. au/2018/04/towards-ecological-democracy/

Hollo, T. (2018b). Towards ecological democracy - part 2. Retrieved February 26, 2019, from https://greenagenda.org.au/2018/04/ towards-ecological-democracy-2/

International Telecommunication Union (ITU). (2015). ITU-T Focus Group on Smart Sustainable Cities Standardization: Standardization roadmap for smart sustainable cities (FG-SSC 03/2015). Geneva.

Iskandar Regional Development Authority (IRDA). (2017). Smart city Iskandar Malaysia. Johor Bahru: Iskandar Regional Development Authority.

Jalaluddin, A. M., Lim, S. B., \& Zurinah, T. (2019). Understanding the issues of citizen participation. Journal of Nusantara Studies, 4(1), 1-22. https://doi.org/10.24200/jonus. vol4iss1pp1-22

Joeman, B. D. (2013). Iskandar Malaysia's smart city framework. 4th High Level Seminar on Environmentally Sustainable Cities Programme, Hanoi, 21-22 March.

Johari, Z. K. (2019). Penang 2030: A vision for our future. Retrieved April 21, 2019, from http://www.zairil.com/penang-2030-avision-for-our-future/

Jomo, K. S., \& Wee, C. H. (2002). The Political Economy of Malaysian federalism: Economic Development, Public Policy and Conflict Containment (No. Research Discussion Paper No. 2002/113).

Kaika, M. (2017). "Don't call me resilient again!": The New Urban Agenda as immunology ... or ... What happens when communities refuse to be vaccinated with 'smart cities' and indicators. Environment and Urbanization, 29(1), 89-102.

Kakonen, M., \& Hirsh, P. (2009). The Antipolitics of Mekong knowledge production. In F. T. M. Francois \& M. Kakonen (Eds.), Contested waterscapes in the Mekong Region. London: Earthscan. 
Kathleen, F. (2019). Lost world: How Singapore' s hunger for sand is destroying Cambodia's coastlines and villages. Retrieved April 16, 2019, from https://www.theonlinecitizen. com/2019/03/15/lost-world-howsingapores-hunger-for-sand-is-destroyingcambodias-coastlines-and-villages/

Keitsch, M. (2018). Structuring ethical interpretations of the sustainable development goals-Concepts, implications and progress. Sustainability, 10(829), 1-9. https://doi.org/10.3390/su10030829

Khairul Anwar, M. A. (2019). Henti segera lombong pasir di perairan Perak. Retrieved April 12, 2020, from https://www. sinarharian.com.my/article/35709/EDISI/ Perak/Henti-segera-lombong-pasir-diperairan-Perak

Kitchin, R. (2016). The ethics of smart cities and urban science. Philosophical Transactions of the Royal Society A: Mathematical, Physical and Engineering Sciences. https:// doi.org/10.1098/rsta.2016.0115

Kitchin, R., Coletta, C., Evans, L., Heaphy, L., \& Donncha, D. Mac. (2017). Smart cities, urban technocrats, epistemic communities and advocacy coalitions (No. The Programmable City Working Paper 26). National University of Ireland Maynooth.

Komninos, N., \& Mora, L. (2018). Exploring the big picture of smart city research. Scienze Regionali - The Italian Journal of Regional Science, 17(1), 15-38.

Kostakis, V., \& Bauwens, M. (2014). Network society and future scenarios for a collaborative economy. New York: Palgrave Macmillan.

KPKT. (2019). Malaysia Smart City Framework. Putrajaya: Kementerian Perumahan dan Kerajaan Tempatan.

Kummitha, R. K. R., \& Crutzen, N. (2017). How do we understand smart cities? An evolutionary perspective. Cities, 67, 43-52.

Kurer, O. (1996). The political foundations of economic development policies. The
Journal of Development Studies, 32(5), 645-668.

Lee, J., \& Lee, H. (2014). Developing and validating a citizen-centric typology for smart city services. Government Information Quarterly, 31, S93-S105.

Lim, S. B. (2005). A comparative study of technology firms in Tsukuba Science City, Japan and Kulim Hi-Tech Park, Malaysia. MSc. thesis, Universiti Teknologi Malaysia.

Lim, S. B. (2020). Membina model bandar pintar berpusatkan rakyat di Malaysia. $\mathrm{PhD}$ thesis, Universiti Kebangsaan Malaysia.

Lim, S. B., Jalaluddin, A. M., Mohd Yusof, H., \& Zurinah, T. (2018). Citizen participation in building citizen-centric smart cities. Geografia, 14(4), 42-53.

Lim, S. B., Jalaluddin, A. M., Mohd Yusof, H., \& Zurinah, T. (2020). Understanding the trends and characteristics of smart urbanism across continents. Smart Cities and Regional Development Journal, 4(1), 23-35.

Little, L. (2019). 60 Minutes: Australia's recycling lie exposed: Plastics being dumped, buried and burned in Malaysia. Retrieved April 20, 2019, from https:// www.9news.com.au/national/60-minutesplastic-australian-recycling-malaysiachina/e 1 a $06745-9$ b3 5-4b $15-85$ cb32168 ef9b440

Lockie, S. (2001). SIA in review: Setting the agenda for impact assessment in the 21st century. Impact Assessment and Project Appraisal, 19(4), 277-287.

Loo, C.(2019). Ministry launches Malaysia Smart City Framework. Retrieved September 25, 2019, from https://www.thesundaily.my/ local/ministry-launches-malaysia-smartcity-framework-BN1395377

Luque-Ayala, A., \& Marvin, S. (2015). Developing a critical understanding of smart urbanism? Urban Studies, 52(12), 2105-2116. 
Maboloc, C. R. (2016). On the ethical and democratic deficits of environmental pragmatism. Journal of Human Values, 22(2), 107-114.

Madakam, S., \& Ramaswamy, R. (2016). Sustainable smart city: Masdar (UAE) (A city: ecologically balanced). Indian Journal of Science and Technology, 9, 1-8.

Majlis Bandaraya Petaling Jaya dan Unit Perundingan Universiti Malaya (MBPJ \& UPUM). (2016). Kajian Impak LA21 di Petaling Jaya. Petaling Jaya: Majlis Bandaraya Petaling Jaya.

Malaysia. (2015). Eleventh Malaysia Plan strategy paper 15: Driving ICT in the knowledge economy. Putrajaya: Economic Planning Unit Prime Minister's Department.

Malaysia. (2019). Shared Prosperity Vision 2030. Putrajaya: Ministry of Economic Affairs.

Mansor, L. (2019). PM: Malaysia making good progress on SDGs. Retrieved April 12, 2020, from https:/www.nst.com.my/news/ nation/2019/09/524734/pm-malaysiamaking-good-progress-sdgs

Marrone, M., \& Hammerle, M. (2018). Smart cities: A review and analysis of stakeholders' literature. Business \& Information Systems Engineering, 60(3), 197-213.

Marsal-Llacuna, M. L. (2015). Building universal socio-cultural indicators for standardizing the safeguarding of citizens' rights in smart cities. Social Indicators Research, 130(2), 563-579.

Maslow, A. (1943). A theory of human motivation. Psychological Review, 50, 370396.

MBPJ. (2019). Community dashboard: Collaborative stakeholders. Retrieved March 19, 2019, from https://www.pjkcd. netcollaborative-stakeholders

MBPJ. (2020). Lawatan dari SUK Perak ke PJ Smart Centre. Retrieved March 30, 2020, from https://www.facebook. com/pg/petalingjayacitycouncil/ photos $/$ ? t a b = a l bu m \& a lbu m $\mathrm{id}=2786729284695557 \&$ \& tn_ =-UC-R

McCarthy, J., \& Prudham, S. (2004). Neoliberal nature and the nature of neoliberalism. Geoforum, 35, 275-283.

McDonald-Wilmsen, B., \& Webber, M. (2010). Dams and displacement: Raising the standard and broadening the research agenda. Water Alternatives, 3(2), 142-161.

Mcintyre, I. (2019). Penang-based fishermen against efforts to train them for other jobs. Retrieved July 25, 2019, from https:// www.thesundaily.my/local/penang-basedfishermen-against-efforts-to-train-themfor-other-jobs-FC1105403

Muzaffar, C. (1986). Freedom in fetters: An analysis of the state of democracy in Malaysia. Penang: Aliran Kesedaran Negara (ALIRAN).

National Institute of Standards and Technology (NIST). (2014). Global city teams challenge Kick-off. Retrieved December 14, 2018, from US Department of Commerce website: http://www.nist.gov/cps/global-city-teamschallenge-workshop.cfm

Netto,A.N.(2019). It's not about 'compensation': Creative, colourful fishermen' s protest has changed the dynamics. Retrieved July 25, 2019, from https://anilnetto.com/economy/ development-issues/colourful-fishermensprotest-has-changed-the-dynamics/

Niaros, V. (2016). Introducing a taxonomy of the "smart city": Towards a commons-oriented approach? TripleC, 14(1), 51-61.

Niemeyer, S. (2020). Deliberation and ecological democracy: From citizen to global system. Journal of Environmental Policy and Planning, 22(1), 16-29. https://doi.org/10.1 080/1523908X.2019.1661232

Nor-Hisham, B. M. S., \& Ho, P. (2015). The Perception of Land Rights Impacts due to the Abolition of a Native Title (NT): Evidence from the Bakun Hydroelectric Project (BHP) and the Kelau Dam Project 
(KDP) in Malaysia. International Review for Spatial Planning and Sustainable Development, 3(1), 98-118.

Nor-Hisham, B. M. S., \& Ho, P. (2016). A conditional trinity as "no-go" against non-credible development? Resettlement, customary rights and Malaysia's Kelau Dam. The Journal of Peasant Studies, 43(6), 1177-1205.

Nordin, R. (2020). Groundwork to build a smart city. Retrieved April 12, 2020, from https://www.thestar.com.my/metro/metronews/2020/02/19/groundwork-to-build-asmart-city

Norhayati Umor. (2017). Petaling Jaya ke arah smart city. Retrieved January 1, 2017, from selangorkini.my website: https:// selangorkini.my/2017/12/petaling-jaya-kearah-smart-city/

Oon, A. J. (2018a). Illegal factories in Selangor have turned Malaysia into a plastic waste dumping ground. Retrieved April 21, 2019, from https://says.com/my/news/plasticdumping-malaysia

Oon, A. J. (2018b). Ministers vow stricter action against selangor's illegal plastic waste recycling factories. Retrieved April 21, 2019, from https://says.com/my/news/ politicians-illegal-plastic-waste-factories

Ostrom, E. (1990). Governing the commons: The evolution of institutions for collective action. Cambridge: Cambridge University Press.

Pascoe, B. (2014). Dark Emu: Lack seeds: Agriculture or accident? Australia: Magabala Books.

Patunru, A. A., \& Haryoko, A. (2015). Reducing deforestation by strengthening communal property rights. Jakarta: Center for Indonesian Policy Studies (CIPS).

Perreault, T., Bridge, G., \& McCarthy, J. (2015). The Routledge handbook of political ecology. London: Routledge.
Peters, M. A. (2017). Education for ecological democracy. Educational Philosophy and Theory, 49(10), 941-945. https://doi.org/10. 1080/00131857.2017.1339408

Plumwood, V. (2002). Environmental culture: The ecological crisis of reason. Routledge.

Poole, S. (2014). The truth about smart cities: In the end, they will destroy democracy. Retrieved November 11, 2018, from http:// www.theguardian.com/cities/2014/dec/17/ truth-smart- city-destroy- democracyurban-thinkers-buzzphrase

Preston, P. W. (1996). Development theory: An introduction. Oxford: Blackwell Publishers.

Qatar. (2014). Sustainable smart cities: improving quality of life (smart Qatar). Retrieved from http://www.motc.gov. $\mathrm{qa} /$ sites/default/files/sustainable_smart cities_-_improving_quality_of_life.pdf

Sachs, J., Schmidt-Traub, G., Kroll, C., Lafortune, G., \& Fuller, G. (2018). SDG Index and Dashboards Report 2018: Global Responsibilities. New York: Bertelsmann Stiftung and Sustainable Development Solutions Network (SDSN).

Sawyer, S., \& Gomez, E. T. (2012). The Politics of Resource Extraction: Indigenous People, Multinational Corporations and the State. New York, United States of America (USA), United Nations Research Institute for Social Development (UNRISD).

Schlosberg, D., Bäckstrand, K., \& Pickering, J. (2019). Reconciling ecological and democratic values: Recent perspectives on ecological democracy. Environmental Values, 28(1), 1-8. https://doi.org/10.3197/ 096327119X15445433913541

Selinger, M., \& Kim, T. (2015). Smart city needs smart people: Songdo and Smart+ Connected Learning. In D. Araya (Ed.), Smart cities as democratic ecologies (pp. 159-172). New York: Palgrave Macmillan.

Sloane-White, P., \& Beaulieu, I. (2010). Beyond 50 years of political stability in Malaysia; rent and the weapons of the power elite. 
Canadian Journal of Development Studies, 30(3-4), 381-402.

Smart Selangor Delivery Unit (SSDU). (2016). Smart Selangor executive summary 2016. Shah Alam: Menteri Besar Selangor Inc.

Soderstrom, O., Paasche, T., \& Klauser, F. (2014). Smart cities as corporate storytelling. City, 18(3), 307-320.

Soo, W. J. (2019). Sungai Kim Kim pollution started years ago, says ecologist. Retrieved April 20, 2019, from https:// www.freemalaysiatoday.com/category/ nation/2019/03/15/sungai-kim-kimpollution-started-years-ago-says-ecologist/

Sunstein, C. R. (1993). Democracy and the problem of free speech. New York: The Free Press.

Syajaratulhada, M. R. (2020). Anwar jumpa Kon Yeow bincang projek tambak laut. Retrieved April 12, 2020, from https:// www.sinarharian.com.my/article/37574/ EDISI/Utara/Anwar-jumpa-Kon-Yeowbincang-projek-tambak-laut

Tan, B. (2019). Police nab two key suspects over Sungai Kim Kim toxic pollution. Retrieved April 20, 2019, from https://www.malaymail.com/news/ malaysia/2019/03/19/police-nab-twokey-suspects-over-sungai-kim-kim-toxicpollution/1734378

Tan, B. (2020). Pasir Gudang pioneers Malaysia's first early warning system for air pollution. Retrieved March 3, 2020, from https://www.malaymail.com/news/ malaysia/2020/02/23/pasir-gudangpioneers-malaysias-first-early-warningsystem-for-air-pollutio/1840048

Tan, L. I. (2019). Penang: Becoming a smart state. Penang Institute Issues, (Sept), 1-11.

Tang, T. (2018). Mahathir is back — good news or bad for sustainability in Malaysia? Retrieved April 21, 2019, from https://www. eco-business.com/opinion/mahathir-isbackgood-news-or-bad-for-sustainabilityin-malaysia/ thestar. (2019). Johor seeks more time to tackle pollution issue. Retrieved April 12, 2020, from https://www.thestar.com.my/news/ nation/2019/07/23/johor-seeks-more-timeto-tackle-pollution-issue

Thomas, R. D. (2013). Understanding Public Policy (Fourteen Edition). USA: Pearson Education Limited.

Trisha, N. (2019). Penang fishermen protest reclamation project, say it will affect their livelihoods. Retrieved April 12, 2020, from https://www.thestar.com.my/news/ nation/2019/11/04/penang-fishermenprotest-reclamation-project-say-it-willaffect-their-livelihoods

United Nations (UN). (n.d.-a). About the Sustainable Development Goals. Retrieved February 26, 2019, from https:// www.un.org/sustainabledevelopment/ sustainable-development-goals/

United Nations (UN). (n.d.-b). The sustainable development agenda: 17 goals to transform our world. Retrieved April 7, 2019, from https://www.un.org/ sustainabledevelopment/developmentagenda/

United Nations (UN). (2001). Security Council Condemns Illegal Exploitation of Democratic Republic of Congo's Natural Resources. Meetings Coverage and Press Releases, 4317th and 4318th Meetings (AM and PM).

United Nations (UN). (2014). World urbanization prospects: The 2014 revision highlights. New York: United Nations.

United Nations (UN). (2018). The Sustainable Development Goals Report 2018. https:// doi.org/10.29171/azu_acku_pamphlet_ k3240_s878_2016

Vigoda, E. (2002). From responsiveness to collaboration: Governance, citizens, and the next generation of public administration. Pub. Admin. Review, 62(5), 527-540. 
Walker, P. A. (2005). Political ecology: Where is the ecology? Progress in Human Geography, 29(1), 73-82.

White, J. M. (2016). Anticipatory logics of the smart city's global imaginary. Urban Geography, 37(4), 572-589.

Wiig, A. (2016). The empty rhetoric of the smart city: From digital inclusion to economic promotion in Philadelphia. Urban Geography, 37(4), 535-553.

Willis, K. (2019). Whose right to the smart city? In R. Kitchen, P. Cardullo, \& C. di Feliciantonio (Eds.), The right to the Smart City. https://doi.org/10.2307/j.ctt1t899cr.9

Wong, J. S. Z. (2019). PSR, PTMP keys to unlocking Penang' s sustainable future. Retrieved April 27, 2019, from https:// www.themalaysianinsight.com/s/149185

World Commission on Environment and Development (WCED). (1987). Our common future. New York: Oxford University Press.

Yeoh, M. (2019). Enhancing partnership for Sustainable Development Goals. Retrieved April 12, 2020, from https://www.thestar. com.my/opinion/letters/2019/11/06/ enhancing-partnership-for-sustainabledevelopment-goals

Yigitcanlar, T., Foth, M., \& Kamruzzaman, M. (2019). Towards post-anthropocentric cities: Reconceptualizing smart cities to evade urban ecocide. Journal of Urban Technology, 26(2), 147-152.

Yin, R. K. (2018). Case study research and applications: Design and methods (6th ed.). Thousand Oaks: Sage.

Zamali, M., \& Lee, S. C. (1991). Proposed management guidelines for offshore sand mining activities in South Johore, Malaysia. ICLARM Conference Proceedings 22, 455. National University of Singapore, 365-373. 
Appendix: Comparisons of the Characteristics of Capitalism and Ecological Democracy

Capitalism/ Liberal Democracy

(Centralist liberalism, Fascism)
Ecological Democracy

(Left politics; Green Politics/ The Commons)

\section{General}

- (Dominant) Context of disconnection

-Alienation - (nothing is connected, encouraged to compete, atomized, all is abstract)

- Liberal representative of democracy

- Disenfranchisement

- Treat nature as inexhaustible resource to be endlessly abused

- (Alternative) Green politics

- The commons (everything in its grand messy diversity is connected to nature)

- Matching indigenous social systems and political movement: share resources, keep it healthy, prevent freeloaders, share profits

- Cooperative governance to ensure long-term stability for communities in and with the living world

- New space: rejecting the binary choice between privatization and public ownership

- Not to treat participatory policy as an add-on to the representative models, but build a range of deeper participatory processes and embed them in institutions

- Equity, sustainability - embedded in nature

- A politics of full franchise, institutionalized stewardship, deinstitutionalized selfishness, interconnection and reclaimed commons.

- Intersectional politics, understand inequalities and all classes

- Seek to find systemic responses through cooperative processes

\section{Market/ Corporation's Role}

- As opportunists

- As public value contributors or mediators

- As profit-driven service providers or mediators

- Corporations play a big role in mediating (provide technological solutions) between government and customers

- Privatization, profits from public resources

- Upload free-riding - behavior which profits at the expense of people and the planet

- As anathema to the idea of privatising profits from public resources

- Humanity has no future unless we stop plundering nature

- Prevent abuse

- Not enough to socialize enterprises without transforming them based on respect for the vital cycles of nature and social well-being

- A left politics implies strong regulation of corporations and markets to prevent free riding

- Uphold cooperation and trust, implies high taxes on the rich and substantial redistribution of wealth 


\section{The State/ Government/ Public \\ Administrator's Role}

- As rulers

- As trustees

- As managers

- As service providers (but has become no longer has any real presence in lives)

- Public ownership

- Authoritarian

- Paternalism

- Centralization

- Representative decision-making style

\section{The Citizen's Role}

- As beneficiary - customers, constrained passive users

- No capacity to play any active role (described as democratic deficit)

- As a data contributor, mostly in passive mode, in exchange of convenience, in a conscious or unconscious manner

- As a subject of governance

- As voters to vote leaders (undermined the power of voting)
- As coordinator

- As subjects of governance

- Government to respect the participatory outcomes from citizens

- Nationalizing is not the only solution

- Extractivism can never be sustainable

-Whatever form of ownership - private, public or mutual regulation and culture must ensure respectful treatment of people and the planet

- True participatory and 'commoning' processes

- Depoliticize - leave major decisions to experts, collective opinions

- Public ownership still has a key role, but appreciate alternative approaches such as worker- and user-owned cooperatives and other forms of community democratic ownership and management

- To provide an enabling, nurturing environment for people and the planet

- Build a new institution of power

- Get out of the way of business, but maintain strict social order

- As experts, provided with the capabilities of specific knowledge, organizing ability

- As a leader, leading when the government is weak

- As prosumer- act as producer and consumer (e.g., in smart energy)

- As an entrepreneur who is embedding nature, society and profit

- In common indigenous concept: people as temporal custodians, individuals were responsible for trees, people work in cooperation.

- A jig-sawed mutualism operation system

- Community to reclaimed planning for private interests, but also to build positive experiences of participatory democracy and to embed them into political practice

Source: Hollo (2018a; 2018b); Kitchin (2016); Cardullo \& Kitchin (2018); de Waal \& Dignum (2017); Vigoda (2002); Lim et al., (2018); Bollier (2014); Ostrom (1990); Plumwood (2002); and Pascoe (2014) 